\title{
CHRISTINA ROSSETTI AND THE PRE-RAPHAELITES
}

In his survey of the 'countercultural' presence of the Oxford Movement, John Shelton Reed notes that its history 'comes in two parts, one relatively well known, the other largely forgotten' (Reed 1996: 7). Concentrating on poems and paintings produced by Christina Rossetti and the Pre-Raphaelites after John Henry Newman's secession in 1845 and during the second, 'largely forgotten' phase of the Oxford Movement's activity, this chapter considers a complex web of influences. In what follows, I show how Tractarianism informed the early PreRaphaelite aesthetic and how Rossetti took this aesthetic forward and, in turn, used it to inform and disseminate Anglo-Catholic theology. Revealing how her work engaged dialogically with the writings of the leaders of the Oxford Movement, I propose a fresh consideration of the subject and present her as a key participant in the maturation of the Oxford Movement's theology rather than simply as an 'inheritor of the Tractarian devotional mode in poetry' (Tennyson 1980: 198).

\section{TRACTARIAN INFLUENCES ON THE EARLY PRE-RAPHAELITE MOVEMENT}

In 1901, William Michael Rossetti republished the Pre-Raphaelite periodical, The Germ. Although it ran to only four issues in 1850 and was not financially 
profitable, by the end of the century the reputation of the Pre-Raphaelites was soaring and The Germ finally found a receptive audience. In the Preface that he appended to the reprint, William Michael writes that his brother Dante Gabriel's poem 'My Sister's Sleep' (1850) characterises the emphasis on the 'intimate intertexture of a spiritual sense with a material form' that guided the PreRaphaelite Brotherhood in its early stages (W. M. Rossetti 1901: 8). Dante Gabriel's designation of his early poems and paintings as 'Art Catholic' indicates that this emphasis was informed by the Tractarian preoccupation with ancient and medieval hermeneutics (Prettejohn 1999: 45). However, such a straightforward understanding of Tractarian influence is complicated by a consideration of how Dante Gabriel attempted to secularise his 1850 poem in 1870 (Sussman 1972: 7) and by William Michael's disavowal that the Brotherhood 'had anything whatever to do with particular movements in the religious world- whether Roman Catholicism, Anglican Tractarianism, or what not' (W. M. Rossetti 1895: i, 134). While William Michael's comment reveals his brother's movement towards a more 'fleshly' aesthetic, it overlooks the profound connections to the Oxford Movement that other members of the Brotherhood and their associates continued to forge through the second half of the century. Indeed, a survey of Pre-Raphaelite and Tractarian aesthetics from the late 1850s reveals significant places of convergence in aesthetic sensibility.

The influence of the mid-century Tractarian revival of typological and allegorical hermeneutics on the early products of the Pre-Raphaelite Brotherhood can be seen not only in poems such as 'My Sister's Sleep' that draw on elements of the Anglican ritual of the Eucharist (Peters 1979: 266) but also in paintings 
such as John Everett Millais' Christ in the House of His Parents (1849-50).

Significantly, Millais was inspired to paint this after hearing a sermon in Oxford, probably by Edward Bouverie Pusey (Hunt 1905: 114; Barringer 1998: 111). While there can be no doubt that Christ in the House invokes Tractarian typology, Alastair Grieve went so far as to claim that its spatial dynamics draw attention to the space of the High Anglican Church. He suggested how the props in the painting invoke the baptismal font, the roodscreen and the altar and argued that 'the extreme youth of the Baptist and his intention of washing the wound of Christ can be related to the Tractarian emphasis on child baptism and regeneration' (Grieve 1969: 295). While his literal interpretation of the symbolism is far-fetched in places, his article is groundbreaking in that it forges the connection between early Pre-Raphaelite aesthetics and the Ritualist scene in London. Considering this connection on a spiritual level, I want to stress its pervasiveness. Millais was not the only member of the Brotherhood to worship at a High Anglican church in the city. While James Collinson was a regular worshipper at Christ Church, Albany Street before his conversion to Roman Catholicism under John Henry Newman, associates Charles Allston Collins and William Dyce were both committed High Anglicans. Like Millais, all three introduced Tractarian symbolism into their art.

While William Michael records that Dante Gabriel looked back on 'My Sister's Sleep' with distaste (W. M. Rossetti 1901: 17), William Holman Hunt recalls how he had 'completely changed his philosophy, which shewed in his art, leaving monastic sentiment for Epicureanism' (Hunt 1905: ii, 111). Dissatisfied with the emerging Epicureanism of Dante Gabriel and his fellow artists, Collinson 
resigned from the Pre-Raphaelite Brotherhood only two years after it had been established. At this time, the incompatibility of his devotional aesthetic with Dante Gabriel's decadent approach to art was opening up a dissonance between the ideologies of the group members. In her 1853 sonnet, 'The P.R.B,' Rossetti recorded the dispersal of the group as it reached 'its decadence'. The sonnet concludes with the elegiac tercet:

So rivers merge in the perpetual sea, So luscious fruit must fall when over ripe, And so the consummated P.R.B.

(C. Rossetti 2001: 755)

In addition to indicating that the 'fall' of the Brotherhood was inevitable, these lines hint at the impossibility of its members continuing to work towards a common goal: becoming 'over ripe' necessitates decay. In its entirety the sonnet reveals that Rossetti did not include herself among the 'brotherhood' on account of her gender and aesthetic. A further indication of her distance from the group can be seen in William Michael Rossetti's comment that her contributions to The Germ were 'produced without any reference to publication' (W.M. Rossetti 1901: 18). Nonetheless, coupling her ongoing adherence to the aesthetic that William Michael describes with Dante Gabriel's change of philosophy means appreciating how unstable the category of 'Pre-Raphaelite' actually is. Considered in light of William Michael's manifesto statement, it is Rossetti rather than Dante Gabriel who can be most appropriately described as possessing a Pre-Raphaelite sensibility. Revealing the significance of this, Lorraine Janzen Kooistra suggests that it is its 'intimate intertexture' of the spiritual and material that makes 'Christina Rossetti's poetry central to Pre-Raphaelitism from its mid-century 
beginning to its fin-de-siècle renaissance' (Kooistra 2012: 179). This recognition enables an appreciation of how, along with Hunt's paintings that were inspired by biblical typology and analogy, Rossetti's poems are formative in carrying forward the initial vision of the Brotherhood after its dispersal.

An investigation into how the theology of the Oxford Movement has influenced Rossetti's poetry and devotional prose has accompanied the recent concern with reading her work in the light the Pre-Raphaelite vision. Diane D'Amico and David Kent's 2006 survey showcases the breath of scholarship offered by Mary Arseneau, Emma Mason, and Lynda Palazzo in its illumination of Rossetti's engagement with the doctrines of Reserve and Analogy. As Rossetti scholarship continues D'Amico and Kent suggest that her response to 'other specific aspects of Tractarianism might also be explored' (D'Amico and Kent 2006: 101).

\section{ROSSETTI'S TRACTARIAN-INFLECTED VISION OF PERSONHOOD}

In 1843, Rossetti, along with her sister and mother, began attending the newly established Christ Church, Albany Street. In his account of the time he spent serving here, Henry W. Burrows describes 'the zealous earnestness of $\mathrm{Mr}$ Dodsworth and his congregation' and the changes that took place under his leadership (Burrows 1887: 14). Rossetti wrote in February 1873 of her own sentiments regarding these changes in a letter to her friend Caroline Gemmer:

I hope to see Mr Burrows before long, and to deliver your remembrances to him. Christ Church is so improved since the old days of its plainness,- to use no stronger word-: even the far-from-beautiful faith-hope-\&-charity window has been replaced by (I hope) something better'

(C. Rossetti Letters: i, no. 511). 
Rossetti's appreciation of the church's 'improvement' reveals her sympathy with the doctrine of Ritualism that its leaders were promoting. This sympathy is evident in her continued poetic exploration of how the spatial dynamics of the church building showcase the pilgrim's progress towards heaven and offer a fuller appreciation of the Real Presence. Her emphasis on adopting an appropriate posture of worship is testament to the sacramental theology that underlies the placing of the communion table rather than the pulpit as the visual and liturgical focus.

Christina Rossetti's final volume, Verses (1893), collects together 331 lyrics. Only one of these ('Good Friday Morning') was new; the rest were taken from Called to be Saints: The Minor Festivals Devotionally Studied(1881), Time Flies: A Reading Diary (1885) and The Face of the Deep: A Devotional Commentary on the Apocalypse (1892). Comprised of eight sections, Verses enacts the different stages of Christian pilgrimage. Considering its many allusions to liturgical symbols such as incense, candles and crucifixes, Emma Mason writes that 'it is as if Rossetti forges the poem as a church space in the manner of George Herbert in The Temple (1633) or Isaac Williams in The Cathedral(1838), decorating its interior to invite contemplation on deeper religious secrets' (Mason 2004: 123). Arguing that the volume can be read as a 'kind of historical document' and as 'companion piece to Burrows' history of Christ Church,' Mason comments on how the reader is able to 'reconstruct' Rossetti's interest 'in the ritualistic scene so prevalent in Victorian London and in so doing, more clearly perceive her status as a religious commentator as well as poet' (Mason 2004: 
126). The extent to which Rossetti's ritual poetics were circulated among receptive audiences of believers and non-believers is indicated by the fact that twenty-one thousand copies of Verses had been printed by 1914 (W.K.L.C., 1925: 10). The popularity of the volume also points to Rossetti's contribution in sustaining an affective response to Tractarian precept in the latter part of the 'forgotten' second phase of the Oxford Movement.

Throughout the seventeen sonnets that constitute the first series of Verses, "Out of the Deep Have I called unto Thee, O Lord," Rossetti drew the imagery of ceremonial worship and the rhythms of communal utterance. Not only do the sonnets enact Edward Bouverie Pusey's impassioned focus on interior devotion and John Keble's pastoral concerns, they also participate in the task of spiritual direction. The tenth sonnet is particularly dynamic in guiding the pilgrim through different stages of adoration as it moves from apprehension to love and from love to full participation in the communal worship and the place of divine encounter:

O Lord, on Whom we gaze and dare not gaze, Increase our faith that gazing we may see, And seeing love, and loving worship Thee

Thro' all our days, our long and lengthening days.

O Lord, accessible to prayer and praise, Kind Lord, Companion of the two or three, Good Lord, be gracious to all men and me, Lighten our darkness and amend our ways.

Call up our hearts to Thee, that where Thou art

Our treasure and our heart may dwell at one:

Then let the pallid moon pursue her sun, So long as it shall please Thee, far apart,--

Yet art Thou with us, Thou to Whom we run, We hand in hand with Thee and heart in heart. 
In its entirety, the dynamic at work enables the believer to balance a reverential awe that apprehends the fearfulness of God's prerogative to forgive and which stands 'far apart' with an appreciation of His readiness to respond 'to prayer and praise.' Opening with a prayer-like address to God 'on Whom we gaze and dare not gaze,' Rossetti introduces a sacramental dimension. From Goblin Market and Other Poems (1862) to Verses, her work had forged an association between the act of gazing and the act of eating. This association invokes the visual spectacle of the communion table that stands at the centre of the Tractarian church. Allchin suggests that in imitation of the Ancient Fathers, the central Tractarian vision is concerned with bringing 'all human knowledge, activity, and experience into relation to God's revelation of himself' (Allchin1967: 50). As Rossetti's sonnet articulates the battle to 'gaze' heavenward it enacts this process of coming 'into relation' with God's sacramental 'revelation of himself' and thereby works to reinvigorate worshippers as they take from Christ the strength to persevere through 'long and lengthening days.'

Maria Rossetti's letters provide testament to the keen engagement of the Rossetti women with Tractarian discourse. In a one she wrote to her mother Francis in August 1843, Maria recorded her reaction to Newman's discourse on God's guiding presence in his 1836 volume of sermons and to Keble's The Psalter; or, Psalms of David in English verse (1840):

I have read part of Mr. Newman's third volume; I pursued yesterday a sermon entitled 'On a Particular Providence as revealed in the Gospel', which I am sure will please you as much as it does me.

(Angeli-Dennis, box 3: folder 3; Arseneau 2004: 32) 
Considering the closeness of the Rossetti women, it is likely that Christina Rossetti was familiar with the sermon her sister recommends. In it, Newman focused on the character of Hagar and demonstrated how the Scriptures reveal 'God's providential regard for individuals.' Aligning himself with his hearers, he concludes with the encouragement: 'Let us endeavour, by his grace, rightly to understand where we stand, and what He is towards us; most tender and pitiful' (Newman 1891: 561-2). Rossetti's own meditation in Called to be Saints on God's 'minute care' for each individual, and her comment that 'Hagar in need of comfort is as much Hagar to Him as to herself,' indicates that she shared Newman's concern with promoting a greater awareness of 'God's providential regard' (C. Rossetti 1881: 397-8). Reading Rossetti's sonnet alongside this meditation means recognising her commitment to the practical outworking of the Tractarian precept and her vision of God's revelation in the world. As Newman taught believers that they should 'endeavour' to understand their identity in relation to God, Rossetti ushered them into the appropriate posture of adoration and apprehension centred on his Sacrifice.

An element of what Owen Chadwick terms the 'recognisable features' of the 'mind of the Oxford Movement' can be glimpsed in reading John Keble's delineation of God alongside Newman's sermon (Chadwick 1960: 31). The work of both Tractarian leaders demonstrates a profound concern with teaching believers to understand themselves in relation to God's manifestation of himself in the world. In Tract 89 of the Tracts for the Times, 'On the Mysticism Attributed to the Fathers of the Church,' Keble asks readers to imitate the Fathers who developed: 
a deep and reverential sense of God's peculiar Presence and Interference through the whole of this history; a trembling consciousness that they were near the invisible line which separates His agency from that of His rational creatures.

(Keble 1841: iv.15, 87)

In the lines that accompany the first publication of 'O Lord, on Whom we gaze and dare not gaze' in The Face of the Deep: A Devotional Commentary on the Apocalypse (1892), Rossetti reinforces Keble's emphasis on maintaining reverence in the face of God's 'peculiar Presence. She writes, 'Let us not in all our tremblings forget or doubt that it is Faithful Love which speaketh' (C.

Rossetti1893: 15). Rossetti's Tractarian-informed suggestion is that a right apprehension of God enables believers to shape themselves into vehicles of 'trembling of love' and enlarge their hearts as they 'worship Thee.'

The intercessory cry at the heart of Rossetti's sonnet, 'Amend our ways,' re-works the Communion exhortation in the 1662 Book of Common Prayer. 'Amend your lives and be in perfect charity with all men.' By appropriating the exhortation that is to be given by the priest into a communal prayer, Rossetti forges a voice of solidarity rather than one of instruction. Recognising that God is the only one who can 'Amend our ways,' the message is one of grace and encourages a full dependence on God's mercy. The communicant is invited to make the words of the sonnet her own as she apprehends this mercy and partakes of Christ's presence.

Although Rossetti's poetry of the early 1890 s re-works the precepts that had shaped the Tractarian vision of 1830 s and early 1840 s, it is by no means anachronistic. On the contrary, its theology engages with the contemporaneous 
teachings of the London Tractarians who were formative in giving shape to the second phase of the Oxford Movement. These included William Dodsworth, Henry W. Burrows and Richard Frederick Littledale. As her pastors, Dodsworth and Burrows were regular visitors to Rossetti's home in Torrington Square. As her spiritual director and confessor, Littledale corresponded with her regularly and supported her writing. In a letter to Alexander Macmillan asking that he send Littledale a copy of $A$ Pageant and Other Poems, on 22 August 1881 she wrote: he 'is an influential person in more ways than one and friendly towards my work. He did me kind service with the S.P.C.K' (C. Rossetti Letters. ii, no. 931).

The influence of Littledale and others enabled Rossetti's poetry to take on a key role in the dissemination of Tractarian doctrine. Significantly, a number of her poems appeared in seminal Tractarian anthologies. These included Orby Shipley's edited collections of ancient and modern verse, Lyra Mystica: Hymns and Verses on Sacred Subjects (1865), and Lyra Eucharistica: Hymns and Verse on the Holy Communion (1864). The fact that Rossetti's first volume of devotional prose was authorised by Burrows, a key Tractarian figure in mid-nineteenth century London, strengthens the association between her writing and the movement's teaching still further. In her first book of devotional prose, Annus Domini: A Prayer for Each Day of the Year, Founded on Holy Scripture (1874), Rossetti articulates the response of the 'redeemed set free.' In the forward to the volume, Burrows describes its content in terms of 'overflowing charity.' However, he advises caution when he notes that although Rossetti's prayers are 'valuable' for 'their fervour, reverence, and overflowing charity,' since they are all 'addressed to the Second Person in the Blessed Trinity,' they should be 'used as 
supplementary to other devotions' (1874: iii). The 'other devotions' concurrently issued by religious publisher James Parker of Oxford and advertised at the back of the volume include: Augustine's Confessions, Lancelot Andrewes's Devotions, Thomas a' Kempis's Imitation of Christ, and Jeremy Taylor's Holy Living and Holy Dying. As D'Amico and Kent recognise, these advertisements associate 'Rossetti's seemingly rather modest work [...] with major works by prominent men of the Church' (D'Amico and Kent 2004: 56). Reading Rossetti's prayers as 'supplementary' to these traditionally canonical texts means recognising how they participate in the long devotional tradition and rehearse the ongoing and insistent message of dying to self and living in Christ.

The 'zealous earnestness' that Burrows identified at Christ Church (see above) is particularly apparent in Dodsworth's teachings of the late 1840s. In his 1847 sermon, 'The Connection between Outward and Inward Worship,' Dodsworth invoked a concern with ritualism and stressed what the contemporary church can learn from the Jewish Temple and the Temple-service. Throughout, he revealed an impassioned concern with the interior experience of personhood and argued that since the substance represented by Jewish ritual 'is present to us and present with us,' believers should use outward ritual to embody an 'outward expression of their inward perceptions of God' (Dodsworth 1847: 8, 9). He thereby authorises ritual while at the same time correcting the misapprehension that a concern with decoration replaces a commitment to the amendment of individual lives. Eighteen years later and after Dodsworth's conversion to Rome, Littledale took up this same argument and professed his commitment to an Anglo-Catholic ritualism that is based on the practices of the 
Ancient Church. Claiming that "ceremonial worship is the only kind revealed in the Bible,' he stressed the central place that Ritualism should occupy in fostering individual adoration (Littledale1865: 6).

One important lyric neatly illustrates Rossetti's ongoing engagement with the ritualist scene in London that Dodsworth, Burrows and Littledale advocated. Written in 1858 and revised twice over the next thirty-five years, it begins with the prophetic warning, 'Earth has a clear call.' Altering the lyric first for inclusion in Time Flies: A Reading Diary (1885) and next for inclusion in the fifth sequence in Verses, 'Divers Worlds. Time and Eternity,' Rossetti demonstrates her ongoing concern with using poetry to enact 'the connection between outward and inward worship.' The first version of the lyric forms part of the longer unpublished poem "Yet a Little While" (C. Rossetti 2001: 804-6). This poem opens with the lament that "These days are long before I die." Throughout, the speaker proceeds to contemplate how "the downfall of an Autumn leaf", "A young fruit cankered on its stalk" and "A strong bird snared for all his wings" can give rise to pangs of grief. It ends with the hopeful expectation of hearing the "coming chimes" that signal the approach of death:

We have clear call of daily bells,

A dimness where the anthems are,

A chancel vault of sky and star,

A thunder if the organ swells:

Alas our daily life- what else?-

Is not in tune with daily bells

You have deep pause betwixt the chimes

Of earth and heaven, a patient pause

Yet glad with rest by certain laws:

You look and long: while oftentimes

Precursive flush of morning climes

And air vibrates with coming chimes. 
Representing the church as a space prepared for an experience of divine revelation, these lines indicate the spiritual properties of the 'chancel vault' and 'organ.'

In its entirety, the poem's movement away from the Keatesan image of the 'nightingale forlorn' who 'swells her heart to extasy/ Until it bursts and she can die' and towards the 'thunder' that the 'organ swells' is indicative of a shift of vision from the Romantic celebration of nature to the Christian apprehension that elements in the natural world should be understood as types of the Heavenly. By taking the word 'forlorn' from the close of John Keats' 'Ode to a Nightingale,' and by coupling it with the apocalyptic image of the swelling of earthly music as it imbues the spiritual, Rossetti Christianises the Romantic vision of the poet for whom the Brotherhood shared a 'common enthusiasm' and through whom they were brought 'into intimate relation' (Hunt 1905; I, 74). By repeating the word 'swells,' she points to the analogical significance of the earthly and material as it expands to its limits to reveal aspects of the heavenly.

By linking liturgical anthems, the chancel vault and the organ to the urgent call of the 'daily bells', Rossetti imbues them with the characteristics of prophecy. As material receptacles of spiritual substance, they function to stretch the community of worshippers towards the awe of devotion. The description of the 'chancel vault of sky and star' linguistically maps the arching space of the chancel and particularly envisions the Victorian high gothic style of the newly developed Tractarian church, All Saints, Margaret Street. Consecrated in 1859, Rossetti would come to have a more personal attachment to it the following year when her 
sister Maria entered the Sisterhood of All Saints as a novice. Taking up one third of the church, the immense chancel vault creates a dramatic effect as it fosters an appreciative awe of the glories of heaven. Above the ornamental frescos that William Dyce created and the organ pipes, the arched chancel vault is painted royal blue and covered with gold stars. Read in terms of this ecclesiastical space, Rossetti's lyric can be taken as an invitation and warning to the pilgrim who 'look[s] and long[s]' for a glimpse of eternity in the vibrations of the chimes and in the 'Precursive flush of morning climes' that breaks into the space of worship.

By using regular iambic tetrameter to echo the 'thunder' of the organ and its vibrations in the air and by using arched rhyme to replicate the harmony of the church music, the two verses work as a counterpart to Dyce's frescos. Just as the frescos depict the saints looking up to an enthroned Christ, Rossetti's lyric envisions the upward longing of those 'called to be saints' ( 1 Corinthians 1.2). Enabling recognition of the 'deep pause' within which glimpses of eternity are realised, the sounds of the church are imbued with transcendental significance. The 'dimness where the anthems are' invokes the haze of incense accompanying the service and suggests that the sight and sound of the church represent a 'dim' analogical shadow of the eternal.

In her first revision of the 'Earth has a clear call' for Time Flies, Rossetti illuminated the church's precarious standing on the threshold of this 'invisible line' when, among other alterations, she substituted the word 'dimness' for 'rapture' and the word 'sky' for 'gloom':

Earth has a clear call of daily bells, A rapture where the anthems are, 
A chancel-vault of gloom and star, A thunder when the organ swells: Alas, man's daily life- what else?Is out of tune with daily bells.

While Paradise accords the chimes

Of Earth and Heaven: its patient pause

Is rest fulfilling music's laws.

Saints sit and gaze, where oftentimes

Precursive flush of morning climbs

And air vibrates with coming chimes.

In the previous entry, she comments,

The Table of days upon which Easter can possibly fall, shows that there are twelve days which must in all years alike be include among the fortysix week-days and Sundays of Lent.

Of these the $10^{\text {th }}$ of March is the first, the $21^{\text {st }}$ the last.

She concludes this entry with the tentative suggestion that 'for nearly nineteen centuries these twelve solemn days, like twelve Sybils arrayed in mourning robes, have year by year sounded an alarm throughout the Church's holy mountain; calling on the faithful to bewail the past, amend the present, face the future' (C. Rossetti 1885: 50, 49). Incorporating "Earth has a clear call" into the volume to represent the first of these prophetic 'Sybils' accentuates its note of warning. Omitting elements of direct address and adopting the language of collective worship, the second version of the poem also invites recognition of how the rhythms of Paradise are audible to those who are attentive to the music of the church. By changing the words 'You look and long' to 'Saints sit and gaze,' Rossetti exemplifies a move towards a sanctified understanding of communal personhood. Moreover, by describing worshippers as 'saints,' she stresses that responding to the vibrations of Heaven means fulfilling their God-ordained vocation. 
When Rossetti included the poem in Verses, she made further alterations. Switching around the second and third line illuminates the association between earth and the 'chancel-vault.' In using the poem to open the 'Divers Worlds' sequence, Rossetti highlights its allusions to the threshold of heaven. It is from this threshold that the speakers of the subsequent poems receive revelations of the divine. While the warning note of the poem is clear, its new context means recognising that the 'bells' of earth that sound with the 'chimes' of Paradise to disturb 'man's daily life' and call him to the place where 'Saints sit and gaze' indicate a call to authentic personhood. As the other poems of the sequence indicate, this call means reassessing notions of home and belonging. The process whereby the 'man' becomes a 'saint' is explored and the intervention of Christ on earth is shown to be key in revealing personhood and enabling glimpses of salvation.

David Kent argues that the structure of Verses can 'best be described as having two major movements;' with the first four sections centering 'on the speaker's personal growth,' and the second four shifting to 'a more cosmic, impersonal vantage point' (Kent 1979: 261-2). While this description is helpful in bringing the sequential patterning of the volume into critical focus, the category of the 'impersonal' is problematic. An understanding of Rossetti's Tractarian investment in the ancient doctrines of inter-personal growth whereby the personal and the cosmic are inextricably intertwined means reassessing the concept. Theologian Nicholas Lossky proposes that by adhering to a practice of ancient exegesis, the leaders of the Oxford Movement discovered 'the very important difference which exists between the person understood as an individual and what 
ancient theologians would be tempted to call 'true personhood'. He questions the modern understanding of the 'impersonal' when he suggests that 'Personhood for the Fathers - and this is what the Tractarians rediscovered - is revealed by God to humankind' (Lossky 1996: 78-9). They understand that reaching a completely impersonal perspective means moving away from the notion of the self as an isolated entity and towards an awareness of the eternal communion. This is the vision that Rossetti's devotional poems disseminate.

In seeking to foster a Tractarian understanding of personhood, Rossetti's work repeatedly adopts an existential vantage point to blur boundaries between heaven and earth. Charting the process whereby the 'bells' of the world become indistinguishable with the 'chimes' of eternity, and 'man's daily life' becomes intertwined with the experience of the saints who have been redeemed, her poetry realises the vision of the 'intimate intertexture between spiritual sense and material form' that William Michael Rossetti described as a guiding principle of Pre-Raphaelite art. As a consequence, it contributeed to the dissemination of the Oxford Movement in the second half of the nineteenth-century and significantly extended the Tractarian vision of God's imminence and transcendence.

\section{REFERENCES}

Allchin, A.M. (1967). 'The Theological vision of the Oxford Movement.' The Rediscovery of Newman: An Oxford Symposium. Sheed and Ward. pp. 5075.

Arseneau, Mary (2004). Recovering Christina Rossetti: Female Community and Incarnational Poetics. Basingstoke: Palgrave Macmillan.

Barringer, Tim (1998). Reading the Pre-Raphaelites. London: Weidenfield and Nicolson. 
Chadwick, Owen (ed.) (1960). The Mind of the Oxford Movement. London: A. \& C. Black.

D’Amico, Diane, and David Kent (2004). 'Christina Rossetti's Notes on Genesis and Exodus,' Journal of Pre-Raphaelite Studies, 13, pp. 49-98.

-- (2006). 'Rossetti and the Tractarians,' Victorian Poetry, 44 (1), pp. 93-103.

Dodsworth, William (1847). The Connection between Outward and Inward Worship: A Sermon preached in the Parish Church of New Shoreham on Thursday January 21 st, 1847 , on the occasion of offering a new organ for the service of Almighty God. London: F. \& J. Rivingtons.

Grieve, Alistair. (1969). 'The Pre-Raphaelite Brotherhood and the Anglican High Church.' Burlington Magazine, 111, pp. 294-5

Harrison, Antony H. (1988). Christina Rossetti in Context. Brighton: Harvester.

Hunt, William Holman. (1905). Pre-Raphaelitism and the Pre-Raphaelite Brotherhood. London: Macmillan \& Co.

Keble, John (1827). The Christian Year (Oxford: J.H. Parker, 1837),

-- (1841). Tract 89, On the Mysticism Attributed to the Fathers of the Church. In: Tracts for the Times by Members of the University of Oxford, 6 vols. London: J.G.F. \& J. Rivington.

Kent, David A. (1979). 'Sequence and Meaning in Christina Rossetti's Verses (1893).' Victorian Poetry, 17 (3), pp. 259-264.

Kooistra, Lorraine Janzen (2012). 'Christina Rossetti (1830-1894).' In: Elizabeth Prettejohn (ed), The Cambridge Companion to the Pre-Raphaelites. Cambridge: Cambridge University Press. pp. 164-182.

Lossky, Nicolas (1996). 'The Oxford Movement and the Revival of Patristic Theology.' In: Paul Vaiss (ed), From Oxford to the People. Hertfordshire: Gracewing. pp. 78-9.

Littledale, Richard Frederick (1865). Catholic Ritual in the Church of England: Scriptural, Reasonable, Lawful. London: Palmer.

Mason, Emma (2004). "'A Sort of Aesthetico-Catholic Revival." Christina Rossetti and the London Ritualist Scene.' In: David Clifford and Laurence Roussillon (eds), Outsiders Looking in: The Rossettis Then and Now. London: Anthem, pp. 115-130.

Newman, John Henry (1891). 'A Particular Providence as Revealed in the Gospel.' In: Parochial and Plain Sermons, vol. iii. San Francisco: Ignatius Press, pp. 556-565.

Palazzo, Lynda (2002). Christina Rossetti's Feminist Theology. Basingstoke: Palgrave Macmillan.

Peters, J.U. (1979). 'My Sister's Sleep”: Rossetti's Midnight Mass.' Victorian Poetry, 17, pp. 265-268.

Prettejohn, Elizabeth (1999). After the Pre-Raphaelites: Art and Aestheticism in Victorian England. Manchester: Manchester University Press.

Reed, John Shelton (1996). Glorious Battle: The Cultural Politics of Victorian Anglo-Catholicism. Nashville; London: Vanderbilt University Press.

Rossetti, Christina (1874). Annus Domini: A Prayer for Each Day of the Year, Founded on Holy Scripture. London: James Parker \& Co.

-- (1881) Called to Be Saints, The Minor Festivals Devotionally Studied. London: SPCK. 
-- (1885). Time Flies: A Reading Diary. London: SPCK.

-- (1892). The Face of the Deep: A Devotional Commentary on the Apocalypse. 2nd ed. London: SPCK.

-- (1997). Antony H. Harrison (ed.) The Letters of Christina Rossetti. Victorian Literature and Culture Series. Charlottesville ; London: University Press of Virginia.

-- (2001). Christina Rossetti: The Complete Poems, text by R.W. Crump, notes and introduction by Betty S. Flowers. London: Penguin.

Rossetti, William Michael (1895). Dante Gabriel Rossetti. His Family-Letters with a Memoir. London: Ellis.

--- (1904). 'Introduction,' In: The Poetical Works of Christina Georgina Rossetti. London: Macmillan

-- (1901). 'Preface.' The Germ. Thoughts Towards Nature in Poetry, Literature and Art. Being a Facsimile Reprint of the Literary Organ of the Pre-Raphaelite Brotherhood, Published in 1850. London: Elliot Stock.

Sussman, Herbert (1972). 'Rossetti's Changing Style: The Revisions of My Sister's Sleep.' Victorian Newsletter 14, pp. 6-8.

Tennyson, G. B (1981). Victorian Devotional Poetry: The Tractarian Mode. Cambridge, Mass; London: Harvard University Press.

W.K.L.C. (1925). Verses by Christina Rossetti. London: Society for Promoting Christian Knowledge.

\section{$\underline{\text { Manuscripts }}$}

Angeli-Dennis Collection, University of British Columbia Special Collections, Vancouver 